ISSN: 2224-0616

Int. J. Agril. Res. Innov. \& Tech. 6 (2): 87-94, December, 2016 Available online at http://www.ijarit.webs.com

\title{
METABOLIC ALTERATIONS IN LIVER OF FRESH WATER FISH, C. PUNCTATA EXPOSED TO ARSENIC: AN ADVERSE AND ADAPTIVE RESPONSE TO THE ENVIRONMENT
}

\author{
Md. Shahidul Haque1*, Md. Mahmudul Hasan1, Md. Maniruzzaman², Md. \\ Aktaruzzaman 3 , Md. Abu Zubair ${ }^{4}$ and Md. Morshed Rahman ${ }^{5}$
}

Received 30 October 2016, Revised 15 December 2016, Accepted 27 December 2016, Published online 31 December 2016

\begin{abstract}
Arsenic is a major toxicant impairing in diverse metabolic alterations of the organisms and the mechanism of adaptive response is yet to be identified. In the present study, effects of different doses of arsenic in liver of Channa punctata on the regulation of metabolic activities were done. C. punctata, a variety of fresh water fish were exposed to 1, 10 and $1000 \mu \mathrm{M}$ concentration of $\mathrm{Na}_{2} \mathrm{HAsO}_{4}$ for $1 \mathrm{~h}$. The amount of protein, in response to 1,10 and $1000 \mathrm{\mu M}$ concentration of arsenic were augmented by $184.47 \%$ (2.84-folds), $202.82 \%$ (3.0folds) and 317.49\% (4.17-folds), respectively and was found to be higher for $1000 \mu \mathrm{M}$ dose. Cholesterol contents in liver were similarly exaggerated by $517.45 \%$ (6.17-folds), $308.13 \%$ (4.1-folds) and $286.41 \%$ (3.86-folds), respectively. However, the higher response was found for $1 \mathrm{\mu M}$ dose of $\mathrm{Na}_{2} \mathrm{HAsO}_{4}$. Similar stimulatory effects on triglyceride level were observed in response to arsenic. $\mathrm{Na}_{2} \mathrm{HAsO}_{4}$ causes $443.74 \%$ (5.43-folds), $533.11 \%$ (6.33-folds) and $548.48 \%$ (6.48-folds) enhanced triglyceride level in liver respectively and the effects were pronounced for $1000 \mu \mathrm{M}$ concentration. Our findings conclude that arsenic is involved in impairment of metabolic activities in liver of the species of fish and gives an impact to the environment for survival.
\end{abstract}

Keywords: Channa, Liver, Metabolic Regulation, Arsenic, Oxidative Effects

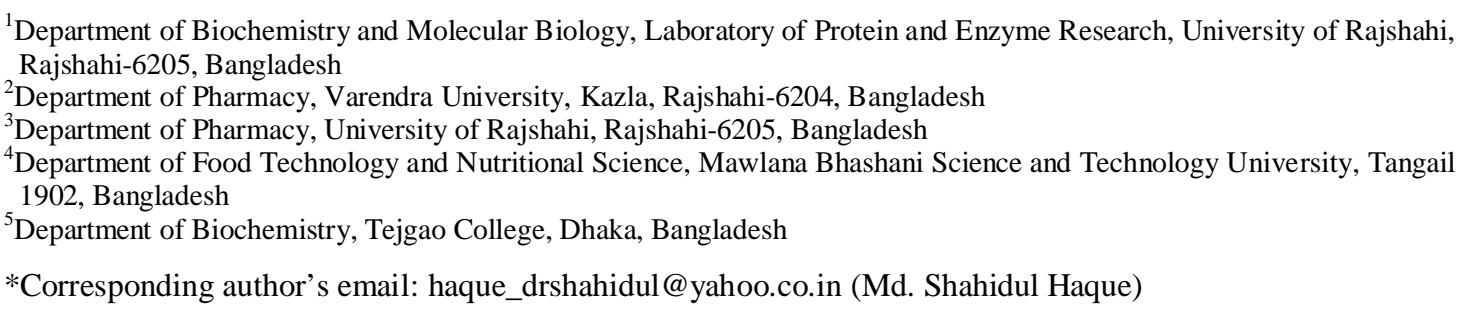

\section{Introduction}

Arsenic is a major toxicant and causes severe oxidative stress to the environment (Samuel et al., 2005; Muthumani and Miltonprabu, 2012). Numerous epidemiological studies have demonstrated that exposure to arsenic is associated with an increased incidence of lung, bladder, and skin cancer, as well as diabetes and cardiovascular disease (Erraguntla et al., 2012). Arsenic is an element that is present at low concentrations everywhere such as in air, soil and water (Gupta et al., 2005). Compounds of arsenic, concentrated in the environment, as a result of natural or anthropogenic sources, become a major concern for environmental and occupational health (Gupta et al., 2005; Rana et al., 2010). Eventually, oxidative stress may occur partially with arsenic toxicity (Kalia et al., 2007; Banerjee et al., 2009). Therefore, it is well recognized that the accumulation of arsenic to the living organism affects metabolic impairment and has been adversely affected to the tissues of aquatic organisms. Among the tissues, liver plays the critical role in metabolic regulation particularly carbohydrate, protein and lipid metabolism. Therefore, arsenic induced metabolic alteration in liver is an important aspect in the current study. It has been demonstrated that exposure of arsenic to aquatic fish causes the formation of oxidative stress (Mahboob, 2013). Oxidative stress is an unavoidable aspect of aerobic life. It is the result of an imbalance between the production of reactive oxygen species (ROS) and antioxidant defences in living organisms (Nishida, 2011). Their findings suggest that antioxidative effects caused by heavy elements might be the synthesis of some essential molecules substantial for the survival of the aquatic fish although not clarified well. 
C. punctata (Taki fish) has been well characterized and is generally found in fresh water of haor, beel and river of Bangladesh. They are much energetic and survive in the critical circumstances for long time. They are the major sources of protein in the diet for human being. It is assumed that the higher energy content of this fish is caused by the increased activity of the sympathetic nerves. Peripheral tissue metabolism is affected by both environmental and chemical stimuli; however, endogenous auto regulation of metabolic processes of all species is a common biological process. To survive in adverse environment, this biological process plays the vital role either the formation of some compounds or degradation of the molecules. Arsenic causes the polluted environment; when the concentration of the pollutants exceeds the normal range, the organisms wants to survive. Therefore, arsenic induced intoxication is an important issue and the regulation of metabolic functions is an important aspect to clarify the mechanism of arsenic toxicity. Studies (Ghatak et al., 2011) on chronic arsenic toxicity have revealed that oxidative stress and hepatic stellate cell activation are key events in arsenic induced liver fibrosis. Increasing the antioxidant capacity of cells thereby has become a therapeutic strategy to antagonize arsenic poisoning (Rana et al., 2010). Degradation of biomolecules as well as biosynthesis is the characteristics of metabolic processes under some special circumstances. Among the peripheral tissues, the skeletal muscle and the liver play a great role in metabolic regulation. The metabolic functions in these tissues are influenced by both environmental and chemical stimuli. Liver glyoogenolysis is a metabolic process yielding energy for doing mechanical work and the process is enhanced upon activation of the sympathetic nervous system. Although, C. punctata has been localized to the environment where the deficiency of water and other adversity have been observed however the survival of these fish to the environment is sometimes impaired by the environmental pollutants particularly when the concentration of the compounds exceeds the normal range. In this circumstance, the alteration of metabolites may enhance the survival to the environment. Therefore, it is necessary to find strategy for the prevention of the toxic effects of arsenic (As) which causes environmental pollution and impairment of metabolic regulation in fish and other aquatic organisms. Although heavy elements like arsenic cause severe oxidative stress and environmental pollution, however survival to the toxic environment is an important aspect for the aquatic organisms and its mechanism is not well characterized and how arsenic is involved in impairment of metabolic activities in liver of this species is not clarified. Therefore, the current study has been undertaken regarding the acute effects of arsenic compounds on the regulation of metabolic activities in liver of fresh water fish C. punctata.

\section{Materials and Methods}

Fish

Channa punctatus weighing $50 \mathrm{~g}$ to $60 \mathrm{~g}$ were used and maintained in normal water with ambient temperature $\left(25.0 \pm 1{ }^{\circ} \mathrm{C}\right)$. In the day of experiment, exposure of arsenic $\left(\mathrm{Na}_{2} \mathrm{HAsO}_{4}\right)$ was given to the different groups of fish in small plastic pots for $1 \mathrm{~h}$ period with full aeration and with free access of water. After the treatment, fish were quickly decapitated and liver was sampled carefully and taken weight by digital balance (Chyo, J L-180, China) and kept at $-20^{\circ} \mathrm{C}$. Control fish were similarly used for sampling of tissue except giving arsenic exposure.

\section{Arsenic treatment}

To examine the role of arsenic on the regulation of metabolic activity involving the amount of protein, triglyceride and cholesterol in liver of C. punctatus, fish were exposed to sodium arsenate $\left(\mathrm{Na}_{2} \mathrm{HAsO}_{4}, \mathrm{BDH}\right.$ Chemical Ltd.) in water (500 $\mathrm{mL}$ ) for $1 \mathrm{~h}$. The groups of fish were treated with different concentration of sodium arsenate $(1,10$ and $\left.1000 \mu \mathrm{M} \mathrm{Na} \mathrm{HAsO}_{4}\right)$ in water $(500 \mathrm{~mL})$ while control fish were exposed to similar volume of water for $1 \mathrm{~h}$ only. The tissue was sampled after the treatment similarly as mentioned above and analyzed for different metabolites.

\section{Assay of tissue protein content}

Tissues were homogenized with pre-cooled water and were centrifuged at $8000 \mathrm{rpm}$ for $10 \mathrm{~min}$. The supernatants from each tissue homogenate were used as crude extract for assay of protein by using $50 \mu \mathrm{L}$ extract. The protein content in tissue was determined by the procedure of Lowry et al. (1951). Briefly, alkaline solution was prepared by mixing $50 \mathrm{~mL}$ of alkaline $\mathrm{Na}_{2} \mathrm{CO}_{3}$ solution $(2 \%$ $\mathrm{Na}_{2} \mathrm{CO}_{3}$ in $0.1 \mathrm{~N} \mathrm{NaOH}$ ) and $1.0 \mathrm{~mL}$ of coppersodium potassium tartarate solution (1 g sodium potassium tartarate and $0.5 \mathrm{~g} \mathrm{CuSO}_{4} .5 \mathrm{H}_{2} \mathrm{O}$ were dissolved in $100 \mathrm{~mL}$ distilled water). Fifty micro liters of tissue extract was taken to the test tube and made up to $1 \mathrm{~mL}$ with distilled water. For blank, $1 \mathrm{ml}$ water was used in place of tissue extract. Five milliliters of alkaline solution was added to each tube and mixed well. The tubes were allowed to stand for $10 \mathrm{~min}$ at room temperature and $0.5 \mathrm{~mL}$ of diluted FCR (Commercial FCR was diluted with equal volume of water) was added and mixed well. After 30 min, the absorbance was taken at $650 \mathrm{~nm}$ against the blank. The protein content in each tissue was calculated from the standard graph of bovine albumin ( $\left.1 \mathrm{mg} \mathrm{mL}^{-1}\right)$ and is expressed as $\mathrm{g}^{100 \mathrm{~g}^{-1}}$ of tissue weight. 
Assay of tissue triglyceride content

Triglyceride content in liver of different groups of fish was measured quantitatively by LABKIT (Triglycerides kits), Crest Biosystems, Bambolim Complex Post Office, Goa - 403 202, INDIA. For assay of triglyceride, $100 \mu \mathrm{L}$ of crude liver sample were used.

\section{Assay of tissue cholesterol content}

Cholesterol content in liver was determined by using the method of Liebermann-Barchard reaction (Kenny, 1952). For assay of cholesterol, $0.5 \mathrm{~mL}$ of crude extract was taken to test tubes and $10 \mathrm{~mL}$ of ethanol-ether mixture (3:1) were added. The test tubes were shaken vigorously and the contents were taken to centrifuge tubes and were centrifuged for $15 \mathrm{~min}$ at $8000 \mathrm{rpm}$. The supernatants were transferred to new glass tubes and evaporated to dryness in a water bath. After evaporation, $5 \mathrm{~mL}$ of chloroform were added to dissolve the residue and $2 \mathrm{~mL}$ of acetic anhydride $-\mathrm{H}_{2} \mathrm{SO}_{4}$ mixture $(20 \mathrm{~mL}$ of acetic anhydride and $1 \mathrm{~mL}$ of concentrated $\mathrm{H}_{2} \mathrm{SO}_{4}$ ) were given, mixed and allowed to stand in dark at $25 \circ \mathrm{C}$ for $20 \mathrm{~min}$ to develop the color. The spectrophotometer reading was taken at $680 \mathrm{~nm}$ against the blank. Cholesterol content was measured with the help of standard solution of cholesterol (20 mg $100 \mathrm{~mL}^{-1}$ in chloroform) where $2.5 \mathrm{~mL}$ of standard solution was taken in test tubes and $2.5 \mathrm{~mL}$ of chloroform were mixed and followed the same procedure. For blank, only 5 $\mathrm{mL}$ of chloroform and $2 \mathrm{~mL}$ of acetic anhydride$\mathrm{H}_{2} \mathrm{SO}_{4}$ mixture were used. The amount of cholesterol was expressed as mg $100 \mathrm{~g}^{-1}$ of tissue weight.

\section{Statistical analysis}

Results of the experiments were expressed as mean and standard error of different groups. The differences between the mean values were evaluated by ANOVA followed by paired t-test using SPSS software.

\section{Results}

Effects of $\mathrm{Na}_{2} \mathrm{HAsO}_{4}$ on protein level in liver of C. punctata

Arsenic causes the formation of oxidative stress and reactive oxygen species (ROS) and thereby making the adverse and toxic environment. However, to survive in such environment liver plays the pivotal role and generates stress proteins. To examine whether sodium arsenate $\left(\mathrm{Na}_{2} \mathrm{HAsO}_{4}\right)$ exposure is involved in the regulation of protein content in liver, groups of fish were treated with different concentrations (1 and 10 and $1000 \mu \mathrm{M}$ ) of $\mathrm{Na}_{2} \mathrm{HAsO}_{4}$ for $1 \mathrm{~h}$. Control fish were used except giving $\mathrm{Na}_{2} \mathrm{HAsO}_{4}$.

Table 1. Effects of arsenic on protein level in liver of C. punctata. The groups of fish were treated with $\mathrm{Na}_{2} \mathrm{HAsO}_{4}(1,10$ and $1000 \mu \mathrm{M})$ for $1 \mathrm{~h}$. After the treatment, the fish were immediately decapitated and sampling of tissue was performed. Control fish were similarly used except giving $\mathrm{Na}_{2} \mathrm{HAsO}_{4}$.

\begin{tabular}{|c|c|}
\hline Treatments & $\begin{array}{c}\text { Protein content } \\
\text { (g } 100 \mathrm{~g}^{1} \text { of tissue weight) }\end{array}$ \\
\hline Control & $10.63 \pm 0.72$ \\
\hline Arsenic $(1 \mu \mathrm{M})$ & $30.24 \pm 2.96 \mathrm{~A}$ \\
\hline Arsenic $(10 \mu \mathrm{M})$ & $32.19 \pm 2.34^{\text {в }}$ \\
\hline Arsenic (1000 $\mu \mathrm{M})$ & $44.38 \pm 7.06^{B}$ \\
\hline
\end{tabular}

The data are means \pm SE for 5 fish in each group. ${ }^{A} \mathrm{p}<0.05$ and ${ }^{\mathrm{B}} \mathrm{p}<0.05$ versus control for $1 \mathrm{~h}$.

As shown in Table 1, the average protein content in liver in response to $\mathrm{Na}_{2} \mathrm{HAsO}_{4}(1 \mu \mathrm{M})$ was $30.24 \pm 2.96 \mathrm{~g} 100 \mathrm{~g}^{-1}$ of tissue whereas for the control liver, the amount of protein was determined as $10.63 \pm 0.72 \mathrm{~g}$. A significant (184.47\%; 2.84-folds, $\mathrm{p}<0.05$ ) increased protein level was observed after $1 \mathrm{~h}$ when compared to the liver of control fish. Another group of fish were exposed to $10 \mu \mathrm{M}$ concentration of $\mathrm{Na}_{2} \mathrm{HAsO}_{4}$ and the amount of protein was recorded as $32.19 \pm$

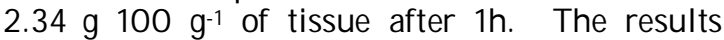
demonstrated that the protein content in liver had been enhanced significantly ( $p$ <0.05) (202.82\%; 3.0-folds) when they were exposed to $10 \mu \mathrm{M}$ concentrations of sodium arsenate, compared to the control fish. The increased protein content was found to be higher for $10 \mu \mathrm{M}$ than that of $1 \mu \mathrm{M}$ concentration (Fig. 1). Similar stimulatory effects were also observed whenever fish were exposed to higher concentrations (1000 $\mu \mathrm{M})$ of $\mathrm{Na}_{2} \mathrm{HAsO}_{4}$ where $\mathrm{Na}_{2} \mathrm{HAsO}_{4}$ causes the formation of protein contents, $44.38 \pm 7.06 \mathrm{~g} 100$ $\mathrm{g}^{-1}$ of tissue. A significant (317.49\%; 4.17-folds, $\mathrm{p}$ $<0.05$ ) increased protein level was observed after 1h when compared to the liver of control fish (Table 1, Fig. 1). The increased synthesis of protein in liver in presence of toxic environment induced by arsenic (As) might be involved in the regulation of metabolic functions of this species of fish. The alteration of protein concentration in liver in response to arsenic is an index for characterization of the sensitivity to the environmental stress. The increased protein in liver may contribute to survival of the species of fish in the toxic environment created by $\mathrm{Na}_{2} \mathrm{HAsO}_{4}$. 


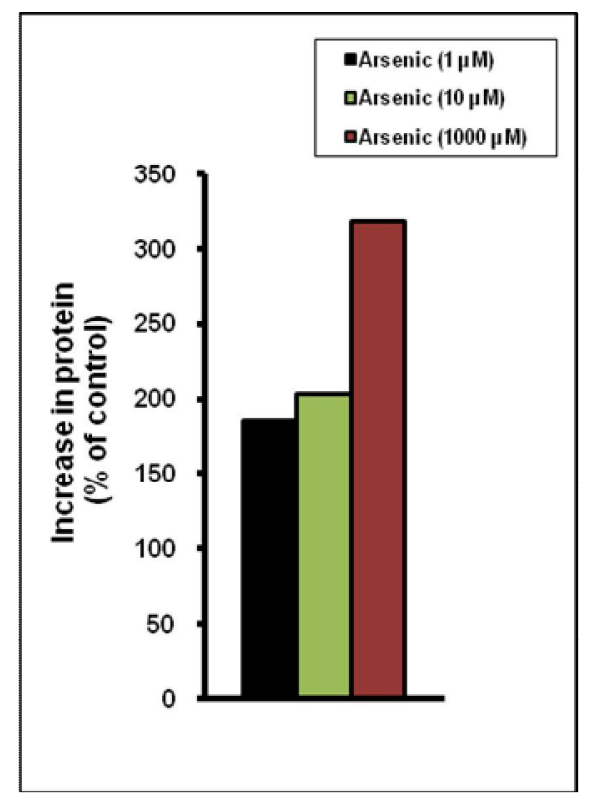

Fig. 1. Increase in metabolite (protein) in liver of C. punctata in response to different concentrations of $\mathrm{Na}_{2} \mathrm{HAsO}_{4}$. The results are expressed as the percentage of control.
Effects of $\mathrm{Na}_{2} \mathrm{HAsO}_{4}$ on cholesterol level in liver of C. punctata

Sodium arsenate $\left(\mathrm{Na}_{2} \mathrm{HAsO}_{4}\right)$ is toxic to the living organisms. Exposure of higher concentration of arsenic in water causes severe effects in fish and might be involved in the impairment of metabolic activities in cellular level. Liver is the major area where biotransformation of foreign toxic substances occurs. The uptake and detoxification of arsenic in liver is an important aspect in liver metabolism. The cellular uptake of arsenic may impair lipid metabolism. To clarify whether $\mathrm{Na}_{2} \mathrm{HAsO}_{4}$ affects cholesterol level in liver, groups of fish (C. punctata) were exposed to $\mathrm{Na}_{2} \mathrm{HAsO}_{4}$ (1 and 10 and $1000 \mu \mathrm{M}$ ). After the treatment, liver was excised and cholesterol content in liver was determined. Control fish were similarly used except $\mathrm{Na}_{2} \mathrm{HAsO}_{4}$ treatment. As shown in Table 2 , the average cholesterol content in liver of fish exposed to $1 \mu \mathrm{M}$ concentration of $\mathrm{Na}_{2} \mathrm{HAsO}_{4}$ was $899.82 \pm 112.65 \mathrm{mg}$ while for the control fish, the value was $145.73 \pm 17.95 \mathrm{mg} 100 \mathrm{~g}^{-1}$ of tissue weight.

Table 2. Effects of arsenic on cholesterol level in liver of C. punctata. The groups of fish were treated with $\mathrm{Na}_{2} \mathrm{HAsO}_{4}(1,10$ and $1000 \mu \mathrm{M})$ for $1 \mathrm{~h}$. After the treatment, the fish were immediately decapitated and sampling of tissue was performed. Control fish were similarly used except giving $\mathrm{Na}_{2} \mathrm{HAsO}_{4}$.

\begin{tabular}{ll}
\hline Treatments & $\begin{array}{l}\text { Cholesterol content } \\
\left(\mathrm{mg} 100 \mathrm{~g}^{-1} \text { of tissue weight }\right)\end{array}$ \\
\hline Control & $145.73 \pm 17.95$ \\
Arsenic $(1 \mu \mathrm{M})$ & $899.82 \pm 112.65^{\mathrm{A}}$ \\
Arsenic $(10 \mu \mathrm{M})$ & $594.78 \pm 51.99^{\mathrm{B}}$ \\
Arsenic $(1000 \mu \mathrm{M})$ & $563.12 \pm 74.10^{\mathrm{B}}$ \\
\hline
\end{tabular}

The data are means \pm SE for 5 fish in each group. ${ }^{A} p<0.001$ and $\mathrm{Bp}<0.001$ versus control for $1 \mathrm{~h}$.

The results show that cholesterol content in liver was increased significantly (517.45\%; 6.17-folds) $(p<0.001)$ when compared to the liver of control fish. Groups of fish were exposed to arsenic with $10 \mu \mathrm{M}$ concentrations of $\mathrm{Na}_{2} \mathrm{HAsO}_{4}$ solution and the cholesterol content in liver was recorded as $594.78 \pm 51.99 \mathrm{mg} 100 \mathrm{~g}^{-1}$ of tissue. The cholesterol level in response to $\mathrm{Na}_{2} \mathrm{HAsO}_{4}$ was found similarly to be increased when compared to control (308.13\%; 4.1-folds; $\mathrm{p}<0.001)$ however the results were found to be lower than that of 1 $\mu \mathrm{M}$ of $\mathrm{Na}_{2} \mathrm{HAsO}_{4}$. The amount of cholesterol was recorded as $563.12 \pm 74.10 \mathrm{mg} 100 \mathrm{~g} \mathrm{~g}^{-1}$ of tissue whenever fish were exposed to $\mathrm{Na}_{2} \mathrm{HAsO}_{4}(1000$ $\mu \mathrm{M})$. The cholesterol content was similarly and significantly increased (286.41\%; 3.86-folds; $\mathrm{p}<$ 0.001 ) in response to higher dose of arsenic compound when compared to control fish (Fig. 2, Table 2) and the results were much lower than that of $1 \mu \mathrm{M}$ of $\mathrm{Na}_{2} \mathrm{HAsO}_{4}$ (Table 2).

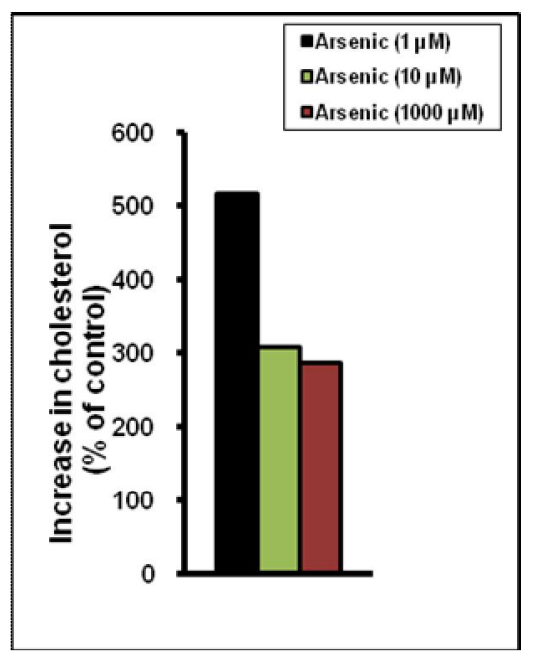

Fig. 2. Increase in metabolite (cholesterol) in liver of C. punctata in response to different concentrations of $\mathrm{Na}_{2} \mathrm{HAsO}_{4}$. The results are expressed as the percentage of control. 
The results would suggest that arsenic causes the toxic environment and oxidative stress might be induced where the species of fish survive, thereby stimulates the synthesis of cholesterol in liver. The higher cholesterol level in liver may play the critical role in survival of the species in such environment. Therefore, it is assumed that both chemical and environmental factors cause the adverse effects and are involved in enhancing the accumulation of cholesterol in liver.

Effects of $\mathrm{Na}_{2} \mathrm{HAsO}_{4}$ on triglyceride level in liver of C. punctata

Triglyceride turnover is a metabolic and biological process and represents a characteristic feature for the organisms so that they can survive in the environment. The synthesis and degradation of triglyceride are essential biochemical process and are influenced by alteration of the environmental stimulation. The toxic effects of arsenic may impair the synthesis of triglyceride in liver. Therefore, to clarify whether $\mathrm{Na}_{2} \mathrm{HAsO}_{4}$ is involved in inducing triglyceride biosynthesis, groups of fish were exposed to different concentrations of $\mathrm{Na}_{2} \mathrm{HAsO}_{4}$ ( 1 and 10 and $1000 \mu \mathrm{M}$ ) to examine the role of arsenic on the changes of triglyceride in liver. As shown in Table 3, the amount of triglyceride in liver of fish in response to $\mathrm{Na}_{2} \mathrm{HAsO}_{4}(1 \mu \mathrm{M})$ for 1h was $89.50 \pm 8.04 \mathrm{mg}$ while for $10 \mu \mathrm{M}$ concentration, the value was found to $104.21 \pm$ $13.51 \mathrm{mg} \mathrm{g}^{-1}$ of tissue weight. On the contrary, the amount of triglyceride in livers of group of fish (control) was recorded as $16.46 \pm 3.07 \mathrm{mg} \mathrm{g}^{-1}$ of tissue weight. A significant increased (443.74\%; 5.43-folds; $\mathrm{p}<0.001$ ) response on triglyceride synthesis in liver was observed for fish exposed to $\mathrm{Na}_{2} \mathrm{HAsO}_{4}(1 \mu \mathrm{M})$. Similar stimulatory effects (533.11\%; 6.33-folds; $\mathrm{p}<0.001$ ) on triglyceride synthesis in liver were observed whenever fish were exposed to $10 \mu \mathrm{M}$ concentrations; however the effects were assumed to be potential for the fish exposed to $10 \mu \mathrm{M}$ concentrations of $\mathrm{Na}_{2} \mathrm{HAsO}_{4}$ rather than that of $1 \mu \mathrm{M}$ dose (Fig. 3). To find the effects of higher concentrations of arsenic, fish were exposed to $1000 \mu \mathrm{M}$ concentration of sodium arsenate. Arsenic causes the formation of higher triglyceride contents (106.74 $\pm 20.89 \mathrm{mg} \mathrm{g}^{-1}$ of tissue weight) in liver after $1 \mathrm{~h}$ and the results are increased by 6.48folds (548.48\%; $\mathrm{p}<0.001)$ when compared to control fish (Table 3, Fig. 3).

Table 3. Effects of arsenic on triglyceride level in liver of C. punctata. The groups of fish were treated with $\mathrm{Na}_{2} \mathrm{HAsO}_{4}(1,10$ and $1000 \mu \mathrm{M})$ for $1 \mathrm{~h}$. After the treatment, the fish were immediately decapitated and sampling of tissue was performed. Control fish were similarly used except giving $\mathrm{Na}_{2} \mathrm{HAsO}_{4}$.

\begin{tabular}{ll}
\hline Treatments & $\begin{array}{l}\text { Triglyceride content } \\
\left(\mathrm{mg} \mathrm{g}^{-1} \text { of tissue weight }\right)^{-}\end{array}$ \\
\hline Control & $16.46 \pm 3.07$ \\
Arsenic $(1 \mu \mathrm{M})$ & $89.50 \pm 8.04^{\mathrm{A}}$ \\
Arsenic $(10 \mu \mathrm{M})$ & $104.21 \pm 13.51^{\mathrm{B}}$ \\
Arsenic $(1000 \mu \mathrm{M})$ & $106.74 \pm 20.89^{\mathrm{B}}$ \\
\hline
\end{tabular}

The data are means \pm SE for 5 fish in each group. ${ }^{A} \mathrm{p}<0.001$ and ${ }^{\mathrm{B}} \mathrm{p}<0.001$ versus control for $1 \mathrm{~h}$.

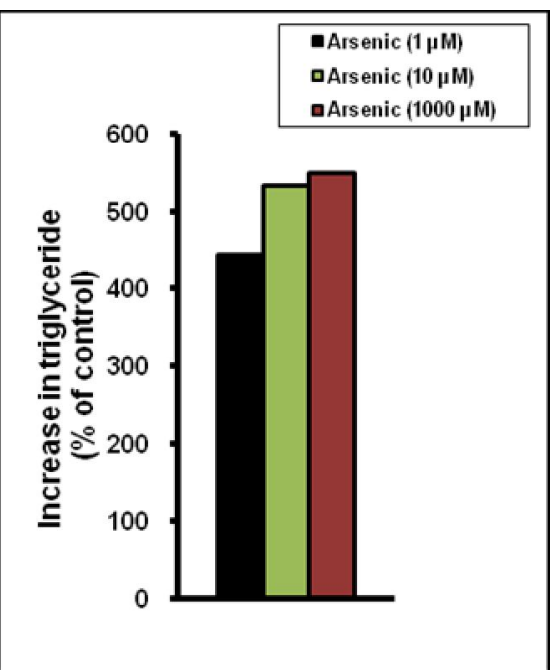

Fig. 3. Increase in metabolite (triglyceride) in liver of C. punctata in response to different concentrations of $\mathrm{Na}_{2} \mathrm{HAsO}_{4}$. The results are expressed as the percentage of control.
The results demonstrated that arsenic had been involved in impairment of triglyceride in liver inducing lipogenesis and would suggest that this heavy element creates an adverse environment and the increased triglyceride in liver may play the critical role to survive in this circumstance.

\section{Discussion}

The metabolic regulation in liver of C. punctata in response to sodium arsenate has been focused in the current investigation. Sodium arsenate $\left(\mathrm{Na}_{2} \mathrm{HAsO}_{4}\right)$ is an arsenic species involved in severe impairment of metabolic processes. The tissue uptake and its severe deleterious effects have been reported in several investigations (Rahman et al., 2009; Ei-Demerdash et al., 2009). Compounds of arsenic concentrated in the environment causing environmental pollution therefore considered to be the major concern for environmental and occupational health. It has been demonstrated that exposure of arsenic to living organisms causes severe oxidative stress (Muthumani and Miltonprabu, 2012) thereby the 
cellular metabolic impairment and tissue damage have been observed. It is therefore the diverse investigations of arsenic are needed and its preventive measure is substantial. In the current investigations, sodium arsenate has been found to be involved in the regulation of metabolism of protein, triglyceride and cholesterol in liver of $\mathrm{C}$. punctata. Short term $(1 \mathrm{~h})$ exposure of arsenic causes severe stimulatory effects on protein, triglyceride and cholesterol content. Although, the mechanism is not clear that how this heavy element causes the higher synthesis of these metabolites, it is assumed that this element might be involved in the higher formation of reactive oxygen species (ROS) and for the adaptive response of the species of fish, these molecules play the critical roles in survival of the species since arsenic has been shown to be involved in causing ROS (Muthumani and Miltonprabu, 2012).

Exposure of arsenic has been shown to trigger protein in liver of C. punctata. To survive in the toxic environment, the organisms may cause the formation of some stress proteins which may play the role in this respect. Arsenicals are also known to induce a number of major stress protein families, including heat shock proteins (hsps) both in vitro and in vivo in several organs and systems with a rapid dose dependent response to acute exposure to arsenite (Gornati et al., 2002). It has been found that arsenic induced liver of aquatic fish shows higher expression of proteins (stress proteins) (Roy and Bhattacharya, 2006) since this protein may act in the defense system. Fish are considered as suitable biomonitors for environmental pollution and they are exposed to the heavy metals in vitro to study the effects of heavy metals in aquatic ecosystems (Padmini et al., 2004). The results are agreement with the present investigation showing the increased protein in liver of $\mathrm{C}$. punctata treated with $\mathrm{Na}_{2} \mathrm{HAsO}_{4}$. Fish treated with $\mathrm{Na}_{2} \mathrm{HAsO}_{4}$ (1, 10 and $1000 \mu \mathrm{M}$ ) shows higher protein contents in liver when compared to control fish. Both chemical and environmental stimuli cause higher oxidative effects therefore, it is reasonable and rational that the protein contents synthesized in liver were found to be higher. The previous study reveals that cold sensitive stress proteins were synthesized in liver of individuals in response to environmental stimuli (Ibarz et al., 2010). Their findings are compatible and correlated with the present investigations.

Cholesterol is another molecule available in liver however the amount of cholesterol in response to $\mathrm{Na}_{2} \mathrm{HAsO}_{4}$ was increased showing the higher lipogenesis in liver. The increased synthesis of cholesterol also may induce higher liver weight and fatty liver and cause lipogenesis as demonstrated by Kumar and Banerjee (2012). In separate experiments, groups of fish were exposed to $\mathrm{Na}_{2} \mathrm{HAsO}_{4}$ for $1 \mathrm{~h}$ and cholesterol contents in liver were recorded. The enhanced cholesterol levels were observed in response to different doses of $\mathrm{Na}_{2} \mathrm{HAsO}_{4}$ when compared to control fish exposed to water only. The increased cholesterol might be due to the higher oxidative effects as these stimuli have been believed to be involved in augmentation of causing of oxidative stress. Moreover, it has been shown that arsenic exposure to fish potentially stimulates the liver cells and increases the total liver mass and lipid content (J ohnston and Dunn, 1987; Kent et al., 1988). Cholesterol is a sterol compound synthesized in liver and is used to produce hormones and cell membranes. It is transported in the blood plasma of all mammals and is required to establish proper membrane permeability and fluidity. Therefore, synthesis of cholesterol in liver may contribute to other functions of the organisms.

Although much evidence were not observed in presence of $\mathrm{Na}_{2} \mathrm{HAsO}_{4}$ on the enhancement of triglyceride, the previous study reveals that arsenic, a potent toxic and heavy element causes the similar effects regarding the synthesis of lipids in liver of fresh water fish (Kumar and Banerjee, 2012). The lipid accumulation, as indicated by the increased number and size of red-stained lipid droplets, was detected in the liver of arsenic-treated fish (Li et al., 2016). The histological phenotype was thus consistent with the transcriptome analysis where up-regulation of fatty acid synthesis and down-regulation of mitochondrial fatty acid $\beta$-oxidation might be observed in the liver of arsenic-treated zebrafish. It is possible that upon arsenic treatment, fat accumulates in the liver as lipid esters in droplets while free fatty acids reduce or remain unchanged. Cellular fatty acid composition is affected and lipid droplets dramatically increased, which could be a result of triglyceride built up and compromised lipoprotein metabolism. Accumulation of lipids can lead to adipogenesis, steatostasis or non-alcoholic fatty liver diseases. The results of the present investigation therefore, are good agreement with their findings. Triglyceride contents in liver were affected in presence of $\mathrm{Na}_{2} \mathrm{HAsO}_{4}$ and demonstrated to be enhanced when compared to the effects of control fish. The lipogenesis is a metabolic process in liver and has been demonstrated to be influenced by the environmental stimulus (Das et al., 2013). Their findings indicate that environmental stress causes the enhancement of gluconeogenesis which might be linked to lipogenesis in liver. The augmented triglyceride in liver of C. punctata in the current investigation when exposed to environmental stress might be also because of the higher oxidative effects. The previous investigations reveal that exposure to heavy elements like arsenic influences fish liver, enhances lipid 
content and total liver mass (J ohnston and Dunn, 1987; Kent et al., 1988). It is therefore, assumed from the above evidence that the increased triglyceride in presence of arsenic is because of the increased lipogenesis process.

Although arsenic induced, augmentation of diverse metabolites in liver has been found in the current study however, the mechanism is not clarified well. Several lines of evidences may support in the arsenic induced mechanism. Antioxidant response is the major cellular defense mechanism that a cell has against arsenic insult. Arsenic-induced antioxidant imbalance has been reported in numerous studies (Valko et al., 2005; Samuel et al., 2005). These studies have demonstrated that various enzymatic and nonenzymatic factors help in protecting cells by scavenging and clearing ROS. The ability of glutathione, the most abundant nonprotein thiol in cells, to react with electrophiles directly or as a cofactor for enzymes (GPx and GST) may play an important role in arsenic detoxification and against arsenic-induced oxidative stress. Mitochondria are the prime targets for arsenic intoxication, either indirectly via ROS accumulation or directly through condensing mitochondrial matrix and opening of permeability transition pores by virtue of its thiol-oxidizing property. In either case, arsenicinduced mitochondrial insult initiates apoptosis (Pulido and Parrish, 2003). Arsenic intensively affects the ROS metabolizing enzymes called antioxidant enzymes, such as SOD, CAT, glutathione peroxidase (GPx), GST, and glutathione reductase (GR). Generally, shortterm exposure to low arsenic concentrations results in an increase in the activity of these enzymes, whereas chronic exposure usually results in their reduction. Arsenic is also known to regulate the activity of thioredoxin reductase, heme oxygenase reductase, and NADPH oxidase in vitro (Kitchin and Conolly, 2010) and it is also known to alter activities of cytochrome P450s. Arsenic is also shown to inhibit pyruvate dehydrogenase (PDH) activity either via oxidative damage or through binding to vicinal dithiols in both pure enzyme and tissue extract. However, its concentration required to deactivate the enzyme is much lower than what is required for direct binding to thiol groups, suggesting an alternative mechanism (Samikkannu et al., 2003).

Although diverse investigations reveal the concept of the mode of arsenic in the biological system, the detoxification of this element is substantial and the strategy finding the prevention of arsenic toxicity is more important in this respect. Prevention of heavy metal toxicity may be accomplished by either reducing the possibility of metal interacting with critical biomolecules and inducing oxidative damage or by increasing the cells antioxidant defenses through endogenous and exogenous supplementation of antioxidant molecules (Kalia et al., 2007). To minimize toxic effects and damages caused by arsenic, cells have improved defense systems, which include antioxidant molecules. When toxic agents against the natural protective systems overrun, exogenous antioxidative and protective compounds must be taken (Devillers et al., 2001). The current investigations reveal that $\mathrm{Na}_{2} \mathrm{HAsO}_{4}$ is a major adaptive and oxidative stress and have been shown to be involved in regulation of the biochemical processes in liver of C. punctata. The regulation of different metabolites in liver of the species may enhance the identification of arsenic induced causes and give the clue to the concept of prevention.

\section{Conclusion}

In the current investigation, diverse metabolic alterations in liver of C. punctata in response to arsenic have been noticed. Arsenic is a major toxicant causing environmental pollution and has been found to be involved in liver metabolic functions. Different doses of arsenic have been severely found to be involved in stimulation of the metabolic activities. Arsenic accumulation in liver affects protein, cholesterol and lipid metabolism. Although the mechanism is not clarified, however it is assumed that the impairment caused by arsenic might be because of the higher oxidative stress. In severe toxic and adverse environment, these species of fish wants to survive. Therefore, current investigation may augment and give a new insight on the adaptive response to the adverse environment for these species of fish.

\section{Acknowledgement}

This study was carried out in the Department of Biochemistry and Molecular Biology, Rajshahi University and was supported by the University Grant Commission (UGC), Bangladesh.

\section{References}

Banerjee, P., Bhattacharyya, S.S., Bhattacharjee, N., Pathak, S., Boujedaini, N., Belon, P. and Khuda-Bukhsh, A.R. 2009. Ascorbic acid combats arsenic-induced oxidative stress in mice liver. Ecotox. Environ. Safe. 72: 639649.

Das, M., Banerjee, B., Choudhury, M.G. and Saha, N. 2013. Environmental hypertonicity causes induction of gluconeogenesis in the airbreathing singhi catfish, Heteropneustes fossilis. PLoS One. 8 (12): e85535.

Devillers, I., Dive, G., De Tollenaere, C., Falmagne, B., de Wergifosse, B., Rees, J.F. and Marchand-Brynaert, J. 2001. Imidazolopyrazinones as potential 
antioxidants. Bioorg. Med. Chem. Lett. 11: 2305-2309.

Ei-Demerdash, F.M., Yousef, M.I. and Radwan, F.M.E. 2009. Ameliorating effect of curcumin on sodium arsenite-induced oxidative damage and lipid peroxidation in different rat organs. Food Chem. Toxicol. 47: 249-254.

Erraguntla, N.K., Sielken, R.L., Jr Valdez-Flores, C. and Grant, R.L. 2012. An updated inhalation unit risk factor for arsenic and inorganic arsenic compounds based on a combined analysis of epidemiology studies. Regul. Toxicol. Pharmacol. 64: 329-341.

Ghatak, S., Biswas, A., Dhali, G.K., Chowdhury, A., Boyer, J.L. and Santra, A. 2011. Oxidative stress and hepatic stellate cell activation are key events in arsenic induced liver fibrosis in mice. Toxicol. Appl. Pharmacol. 251: 59-69.

Gornati, R., Monetti, C., Vigetti, D., Bosisio, S., Fortaner, S., Sabbioni, E., Bernardini, G. and Prati, M. 2002. Arsenic toxicity and Hsp70 expression in Xenopus laevis embryos. Altern. Lab. Anim. 30: 597-603.

Gupta, R., Kanana, G.M., Sharma, M. and Flora, S.J.S. 2005. Therapeutic effects of Moringa oleifera on arsenic-induced toxicity in rats. Environ. Toxicol. Pharmacol. 20: 456-464.

Ibarz, A., Martı'n-Pe'rez, M., Blasco, J., Bellido, D., de Oliveira, E. and Ferna'ndez-Borra's, J. 2010. Gilthead sea bream liver proteome altered at low temperatures by oxidative stress. Proteomics. 10: 1-13.

Johnston, I.A. and Dunn, J. 1987. Temperature acclimation and metabolism in ectotherms with particular reference to teleost fish. Symp. Soc. Exp. Biol. 41: 67-93.

Kalia, K., Narula, G.D., Kanan, G.M. and Flora, S.J.S. 2007. Effects of combined administration of captopril and DMSA on arsenite induced oxidative stress and blood and tissue arsenic concentration in rats. Comp. Biochem. Physiol. Part C. 144: 372379.

Kenny, A.P. 1952. The determination of cholesterol by the Liebermann Burchard reaction. Biochem. J . 52(4): 611-619.

Kent, J ., Koban, M. and Prosser, C.L. 1988. Coldacclimation-induced protein hypertrophy in channel catfish and green sunfish. J . Comp. Physiol. B. 158 (2): 185-198.

Kitchin, K.T. and Conolly, R. 2010. Arsenicinduced carcinogenesis--oxidative stress as a possible mode of action and future research needs for more biologically based risk assessment. Chem. Res. Toxicol. 23(2): 327335.

Kumar, R. and Banerjee, T.K. 2012. Study of sodium arsenite induced biochemical changes on certain biomolecules of the freshwater catfish, Clarias batrachus. Neotrop. Ichthyol. 10 (2): 451-459.

Li, C., Li, P., Tan, Y.M., Lam, S.H., Chan, E.C.Y. and Gong, Z. 2016. Metabolomic characterizations of liver injury caused by acute arsenic toxicity in Zebrafish. PLoS ONE. 11 (3): e0151225.

Lowry, O.H., Rosenbrough, N.J . and Randall, R.J . 1951. Protein measurement with the Folinphenol reagent. J . Biol. Chem. 183: 265-275.

Mahboob, S. 2013. Environmental pollution of heavy metals as a cause of oxidative stress in fish: a review. Life Sci. J. 10: 336-347.

Muthumani, M. and Miltonprabu, S. 2012. Arsenic induced oxidative stress and its possible reversal by chelation therapy. Research and Reviews: A Journal of Toxicology. 2: 16-37.

Nishida, Y. 2011. The chemical process of oxidative stress by copper (II) and iron (III) ions in several neurodegenerative disorders. Monatshefte fur Chemie. 142: 375-384.

Padmini, E., Hepshibha, B.T. and Shellomith, A.S.S. 2004. Lipid alteration as stress markers in grey mullets (Mugil cephalus L.) caused by industrial effluents in Ennore estuary (Oxidative stress in fish). Aquacul. 5 (1): 115-118.

Pulido, M.D. and Parrish, A.R. 2003. Metalinduced apoptosis: mechanisms. Mutat. Res. 533: 227-241.

Rahman, M.M., Ng, J.C. and Naidu, R. 2009. Chronic exposure of arsenic via drinking water and its adverse health impacts on humans. Environ. Geochem. Health. 31: 189-200.

Rana, T., Bera, A.K., Das, S., Pan, D., Bandyopadhyay, S., Bhattacharya, D., De, S., Sikdar, S. and Das, S.K. 2010. Effect of ascorbic acid on blood oxidative stress in experimental chronic arsenicosis in rodents. Food Chem.Toxicol. 48: 1072-1077.

Roy, S. and Bhattacharya, S. 2006. Arsenicinduced histopathology and synthesis of stress proteins in liver and kidney of Channa punctatus. Ecotox. Environ. Safe. 65: 218229.

Samikkannu, T., Chen, C.H., Yih, L.H., Wang, A.S.S., Lin, S.Y., Chen, T.C. and Jan, K.Y. 2003. Reactive oxygen species are involved in arsenic trioxide inhibition of pyruvate dehydrogenase activity. Chem. Res. Toxicol. 16 (3): 409-414.

Samuel, S., Ramanathan, K., Tamilselvan, J . and Panneerselvam, C. 2005. Protein oxidative damage in arsenic induced rat brain: influence of DL-a-lipoic acid. Toxicol. Lett. 155: 27-34.

Valko, M., Morris, H. and Cronin, M.T. 2005. Metals, toxicity and oxidative stress. Curr. Med. Chem. 12 (10): 1161-1208. 